\title{
A Deconstructive Analysis Of The Short Story "Saleema" By Daniyal Mueenuddin
}

\author{
Omama Tanvir \\ MS Scholar, Air University, Islamabad \\ Nazish Amir \\ Lecturer in English, University of Chitral
}

\begin{abstract}
The aim of this research is to apply deconstructive approach to a short story. For this purpose Daniyal Mueenuddin's short story "Saleema” is selected and analyzed. Through deconstruction the feminist reading of the story is dismantled and the power dynamics of the patriarchal Pakistani society are subverted. The research is anchored in Derrida's concept of unreliability of language and Cuddon's idea of reversal of binary oppositions. The paper finds that the protagonist Saleema is not as weak and oppressed as she is perceived to be, rather she is a resilient, independent woman who uses any means possible to get what she wants. The power and authority reside with her and not with any male character. The study is purely qualitative and exploratory in nature.
\end{abstract}

Keywords: Deconstruction, Post-structuralism, Feminism, Daniyal Mueenuddin, In Other Rooms, Other Wonders, Saleema

\subsection{INTRODUCTION}

The current study applies the deconstructive approach presented by Derrida (1976) to the short story "Saleema" written by Daniyal Mueenuddin (2008). Different theorists and critics have defined deconstruction in different ways but all believe in this basic underlying assumption that it emerged as a reaction to Ferdinand de Saussure's idea of structuralism (1950). Deconstruction, also known as applied post structuralism, works against seeing language as a system that constitutes reality (Barry, 2002). According to deconstruction, language is not as reliable a tool for communication as it is believed to be (Derrida, 1979). It establishes the notion of the plurality and fluidity of the meaning (Barry, 2002). Jacques Derrida (1979) developed the concept of deconstruction to counter all the pre-established notions of criticism. It seeks to uncover various loop holes and disunity within the apparently unified texts (Derrida, 1976). As a tool of criticism, this approach has wide applications in literature all over the world. It aims at finding the contradictions, paradoxes, shifts, breaks and tensions within the language (Barry, 2002). However, this approach is quite new to Pakistani literary circles and thus has had little application in the critical analysis of local texts.

Daniyal Mueenuddin's collection of short stories named In Other Rooms, Other Wonders (2008) revolves around the interconnected lives of a wealthy feudal landowner, his servant and 
managers. Under the backdrop of a Pakistani Society, these stories sketch the lives, problems and most specifically the power dynamics etched within the society.

"Saleema" (2008) is one such short story which throws light upon the lowly position of Pakistani women as compared to men in the society. This theme of mistreatment of women is reinforced when Saleema, the protagonist of the story is subjected to abuse at the hands of her father as a child, is ignored by her husband, misused by Hassan, teased by other male servants and is renounced by Rafik when Harouni dies. This paper, however, aims at challenging the feminist reading of the story and establishing Saleema as an independent, dominant entity.

\subsubsection{PROBLEM STATEMENT}

The stereotypical portrayal of women in literature asserts the weak, submissive and irrational tendencies in their nature. The mistreatment of females at the hands of the male members of the society is highlighted in literary works from which generalizations are drawn. İn his short stories, Pakistani writer Daniyal Mueenuddin portrays a very bleak picture of Pakistani society which has caught western readers' attention. His female characters are either, too weak, oppressed or they have no moral standing. The present study aims to challenge this misrepresentation of Pakistani women through deconstruction and seeks to establish them as resilient and strong members of the society.

\subsubsection{RESEARCH OBJECTIVES}

$>$ To dismantle the feminist perspective apparent in short story "Saleema" through deconstruction.

$>$ To investigate the subversion of power dynamics between two genders in short story "Saleema".

\subsubsection{RESEARCH QUESTIONS}

$>$ How does deconstructive analysis dismantle the feminist perspective apparent in short story "Saleema"?

$>$ How have the power dynamics between the two genders been inverted in the short story "Saleema"?

\subsubsection{DELIMITATION OF THE STUDY}

This study is limited to deconstruction of feminism in the short story "Saleema" (2008) written by Daniyal Mueenuddin in his collection of short stories "In Other Rooms, Other Wonders" (2008).

\subsubsection{SIGNFICANCE OF THE STUDY}

This research aims at challenging the stereotypical portayal of women in Pakistani literature. Where feministic analysis shows women as weak, inferior and exploited, deconstruction seeks to turn the tables and invert those binaries with the help of textual cues. Thus, creating a strong, dominant and self-reliant image of Pakistani women. This 
deconstructive analysis propagates the idea that women in this society are not as weak and oppressed as they are portrayed to be, rather they are a force to be reckoned with.

\subsection{LITERATURE REVIEW}

Before embarking on the study, it is necessary to give a review of the work done on the different variables at play in this research. These variables include deconstruction, feminism and the Daniyal Mueenuddin's short story "Saleema" (2008).

Post structuralism criticizes the higher status assigned to language by structuralists (Barry, 2002). It derives its philosophy from Nietzsche's remark "there are no facts, only interpretations" (Barry, 2002). Thus calling into question the commonsensical assumptions, fixed interpretations and paving way for skepticism. The biggest advocate of this concept is Jacques Derrida and his work Structure, Sign and Play in the Discourse of Human Sciences (1966) is considered as the starting point of Post Structuralism. Derrida put forth the idea of a decentered universe by explicating that nothing is absolute or stable (Derrida, 1966). Derrida (1979) further elucidates the slippery nature of language. He explains that the meanings of the words are not embedded within them rather different meanings are assigned to them by different readers (Derrida, 1979). This view is also supported by Culler (1983), according to him deconstruction opposes the idea of "Logo centrism". He establishes the multiplicity and plurality of meaning (Culler, 1983). Lois Tyson (2006) links this concept to semiotics and explains that a sign (word) refers to multiple signifiers (the meaning being associated with it).

Barthes (1968), another key figure in Deconstruction gave the notion of "The Death of the Author" thus liberating the literary text from any possibility of associating it with what the author might have intended. In other words, he asserted that the meaning of a text is not limited to the author or any sort of context (Barthes, 1968).

Deconstruction believes that there is no single reality, truth or identity. It rejects all the previous theories of knowledge and all the established ideologies and notions are challenged (Bauman, 1992). The basic principle of structuralism that reality is constructed by language is rejected. It is something present in the minds and language is only used to express it or to put it into words (Bertens, 2003).

Applied Post Structuralism or Deconstruction, as a method of literary criticism, looks for contradictions and ambiguities within the text to subvert the established meanings. Barbara Johnson defines deconstructive approach in The Critical Difference (1980) as "not synonymous with 'destruction'. It is in fact much closer to the original meaning of the word 'analysis', which etymologically means 'to undo'" (Johnson, 1980).

Similarly Vincent B. Leitch claims in his work Deconstructive Criticism: An Advanced Introduction (1983): "It aims to decipher the stable truths of a work, employing conventional 'passive' tactics of reading; it seeks to question and subvert such truths in an active production of enigmatic undecideables" (Vincent, 1983). It is "a methodological strategy which seeks to 
uncover layers of hidden meaning in a text which have been denied or suppressed" (Hannack \& Taylor, 2001).

Barthes (1968), another key figure in Deconstruction gave the notion of "The Death of the Author" thus liberating the literary text from any possibility of associating it with what the author might have intended. In other words, he asserted that the meaning of a text is not limited to the author or any sort of context (Barthes, 1968).

Peter Barry in his book Beginning Theory (2002) calls deconstructionist approach as "textual harassment or oppositional reading", following Eagleton's view of this method as "reading against the grain or reading against the text itself" (Eagleton, 1996). Barry (2002) outlined the manner in which post structuralists do deconstruction. He also gave a three stage model of the process, comprising of the verbal, textual and linguistic level.

An important facet of post structuralism highlighted by Cuddon (1991) is its ability to reverse the polarity of binary oppositions like day/night, male/female etc. In such binaries one is always superior or privileged while the other is inferior or marginalized.

Deconstruction reverts those binaries by making the inferior one more desirable (Edgar \& Sedgwick, 2007).

Since deconstruction rejects all the pre-established literary theories, it has widespread application in literary circles. This paper is concerned with dismantling of feminist criticism in a short story so a brief overview of the research done in feminism is discussed in order to get an idea of how it works.

According to Lois Tyson (2010) "Feminist criticism explains the way in which literature (and other cultural productions) reinforces or undermines the economic, political, social and psychological oppression of women". This type of criticism evolves from the feminist movement of 1960's and aims at combating the portrayal of women promulgated by literary productions (Barry, 2002). The representation of women in literature contributes in the conditioning of socially acceptable feminine values, which the feminist criticism seeks to challenge. For this purpose a crucial distinction is made between the terms feminist, female and feminine (Moi, 2001).

In 1970's a lot of attention was given to the works of male writers to criticize the stereotypical representation of women in their texts. Soon, a need was realized to give prominence to the neglected women writers and to establish a cannon for them. Elaine Showalter (1999) coined the term "gynocentricism" and distinguished between androtexts and gynotexts on the basis of styles and themes.

Another essential issue in feminist criticism is that of language. Dale Spender (1981) elucidated that "language is not a neutral medium but one that contains many features which reflect its role as the instrument through which patriarchy finds expression (Barry, 2002). 
Feminists believe that language is male-centered. The same idea is suggested by Virginia Woolf in her essay A Room of One's Own (1929).

Helene Cixous (1975) in her essay talk about the importance of the binary male/female. She explains that all the binaries are ultimately related to male/ female binary. Because among them there is always one binary which is prioritized and privileged so it is associated with male whereas the inferior or less desirable one is associated with females (Cixous, 1975).

Feminist criticism and deconstructive criticism are separate forms of literary inquiry but both are often associated with each other. The relationship between two has been explored by Mary Poovey in her essay Feminism and deconstruction (1988). She has explained "how deconstruction calls feminism into question and how feminism can use deconstruction" (Poovey, 1988). Deconstruction can do as much for feminism as feminism can do for deconstruction, however they both cannot be regarded as the mirror images of each other (Elam, 1993).

Deconstruction is relatively new in Pakistani literary circle so not much work has been done in this regard. Lashari and Awan (2012) applied the three stage model of deconstructive analysis presented by Peter Barry (2002) to a short story "The Cow" written by Firdous Haider (1994). The analysis yielded that the story does not convey any single meaning but it can be approached in a number of ways. Same results were achieved when Jawairia Munir (2013) applied the same model to Tariq Rehman's short story "Bingo". Daniyal Mueenuddin's collection of short stories In Other rooms, Other Wonders have been subjected to critical analysis many times. They are most commonly analyzed from a feminist and Marxist perspective. Mushba Said (2016) made a comparative analysis of Manto's and Mueenuddin's short stories to see who presents a more authentic voice of the subaltern. Ambreen Hai (2014) explores the idea of servitude in these stories. All the work done on these stories reiterates the mistreatment of women in every domain but the present study seeks to challenge that through the application of deconstructive approach to short story "Saleema".

\subsection{METHODOLOGY}

The present study challenges the feminist reading of the short story "Saleema" (2008) written by Daniyal Mueenuddin. Deconstructive literary criticism has been done to bring another dimension of Saleema's character to light, a dimension which establishes Saleema as a resilient and independent character. Whereas the inferior and oppressed portrayal established by the feminist perspective has been dismantled. This research falls under the realm of purely qualitative research. An interpretivist approach and descriptive method was used for the analysis and interpretation of the data, which is collected in the form of words.

\subsubsection{SAMPLE}

The sample "Saleema" (2008) is taken from Daniyal Mueenuddin's collection of short stories "In Other Rooms, Other wonders" (2008). It has been selected through purposive 
sampling technique. The story throws light on the precarious condition of women in Pakistani society. However, this generalizing stereotypical portrayal of women is a misrepresentation to some extent, considering the recent shift in positioning of women in the society. The researchers aim to challenge that clichéd depiction of women through the application of deconstructive approach on this short story.

\subsubsection{THEORETICAL FRAMEWORK}

The concept of Deconstruction put forth by Derrida (1979) serve as a theoretical framework to this study. The short story "Saleema" would be analyzed keeping in view Derrida's idea that it is impossible for a text to have fixed interpretations because of the unstable and slippery nature of the language (Derrida, 1979). According to him a text is "no longer a finished corpus of writing, some content enclosed in a book or its margins, but a differential network, a fabric of traces referring endlessly to something other than itself, to other differential traces..." (Derrida, 1979). Deconstruction traces out the unfixed meanings and contradictions inherent within a text and inverts the system of established notions (Barry, 2002). The text would also be analyzed in the light of textual stage of the three stage model put forth by Peter Barry (2002). This stage analyzes the text to look for contradictions at a broader level. It also seeks to investigate the multiple positions a text could take.

Post structuralism rejects the fundamental concept of binary opposition put forth by Structuralism, which believes that a system is classified or divided on the basis of pairs. It establishes the notion of a "decentered world" and dismantling of all reference points (Barry, 2002). Cuddon (1991) points out the difference in these words: "For deconstruction, and poststructuralism, the notion of binary opposition is unsatisfactory because it represents nostalgia for 'self-presence' or 'centering' (Cuddon, 1991)".

Feminist movement has always been a struggle to challenge the hierarchy of sexes established with courtesy of the gender roles. According to a French feminist Simone de Beauvior "This has always been a man's world", (Beauvoir, 1997, p.93). She further clarified that it is a world where man is at the center, he has the authority whereas a woman is relegated to an inferior position. Hence she is marginalized.

Through this study, the researchers aim at dismantling or deconstructing this male/female binary. The polarity has been reversed. The females are placed on a higher pedestal and prioritized whereas the males are the ones who are weak and exploited.

\subsection{DATA ANALYSIS}

This section deals with the deconstructive analysis of the short story "Saleema" written by Daniyal Mueenuddin. "Saleema" tells the tale of a poor girl who has had a very difficult childhood. Her father is a drug addict while her mother sleeps around for money. She is beaten and even sexually abused by her father. The only escape that she finds is when a seemingly eligible man comes from city, marries her and takes her to Lahore. There she starts working as 
a maid in a bureaucrat K.K Harouni's house while her Good-for-Nothing husband is wasted away in drugs. To maintain her position in the new workplace, Saleema offers her body as an object to gain favours.

She begins sleeping with the cook Hassan who soon gets tired of her. When everything seems hopeless, she seduces the senior valet Rafik who is already married and has two sons. Cashing in on the closeness with his boss, Rafik is able to persuade K.K Harouni to let Saleema keep her job even when she is no longer needed. Eventually Saleema and Rafik have a son whom they name Allah Bakhsh. But soon Rafik repents and realizes the wrong he has done to his first wife and sons. When Saleema is let off from her job after Harouni dies, Rafik refuses to take care of her and their son. Distraught she falls prey to drugs and dies while her son is left to beg on the streets.

On the surface level, this story throws light on the precarious condition of women in the Pakistani society, evidencing de Beauvoir's (1975) idea of hierarchy of sexes. Taking the example of Saleema and in an attempt to draw generalizations from it, one comes to realize the gender exploitation prevalent in almost every household, more so in lower and middle class than in elite class. Saleema is subjected to physical and sexual abuse right from a very young age. Her only chance of escape i.e. marriage turns into a cage itself. Her husband's addiction with drugs forces her to seek a job as a maid to support her family. At work place, she is forced to sell her body to the cook in order to save her current employment. She also faces derogatory and insulting remarks by other male staff members.

She is used and discarded on the other person's will as if she's an untouchable. Saleema is left all alone, without any money or job, and has nothing to support her son when Rafik's so called conscience wakes up. Her tragic end raises sympathy in the readers when they realize how badly she has been exploited and oppressed.

Since the aim of this study is to apply deconstructive approach to the short story "Saleema" by Daniyal Mueenuddin, this section seeks to dismantle the feminist perspective within the text. And that is done in the light of the textual stage of the three stage model of deconstruction presented by Peter Barry. The textual stage is concerned with taking an overall view of the text and analysing the plurality of positions the text could take (Barry, 2002). In other words, it analyses the paradoxes and contradictions at the broader level of the text (Barry, 2002). This idea is also propounded by Derrida who stated that there are multiple interpretations of a text (Derrida, 1979).

The deconstructive analysis of the story brings another dimension of Saleema's character to light. She is not as vulnerable and oppressed as one may perceive her to be, neither is she a weak woman who could so easily be used and manipulated by others. Rather she is the one who uses and manipulates others to gain personal benefits. There are many instances in the story to support this argument. First, she uses her husband to get out of the miserable life in that 
backward and small village. When she gets tired of him, she degrades him by labelling him as "weak and depraved" when she herself cannot be considered as morally upright, as at one instance she has been described as "sensuous, unscrupulous and romantic" (Mueenuddin, 2008, p.19).

The story suggests that Saleema has always been more inclined towards the cooks of the houses she had worked for to get small favours. She seduces them so she could get treats from the kitchen. As it is mentioned in the story: "The cooks tempted her, lording it over the kitchen, where she liked to sit, with the smell of broth and green vegetables cooking and sauce." (Mueenuddin, 2008, p. 20). And on another occasion it is mentioned: "Hassan gave her the best parts, things that have gone to the table, foreign things, pistachio ice cream and slices of sweet pies, baked tomatoes stuffed with cheese, potato cutlets, things that she asked for." (Mueenuddin, 2008, p. 20-21)

When Hassan started ignoring her, she knew the "the easy days were over, now she had no one to protect her" (Mueenuddin, 2008, p. 21-22). Here the word "protect" literally means "to cover". So from a deconstructive point of view this statement can be interpreted as how after Hassan got tired of Saleema and gave her a cold shoulder, she realized that now there is no one who would cover for her. So instead of relying on hard and honest labor, she seduced the senior valet Rafik who would stand up for her and help her get her way. She did not consider the wrong she would be doing to Rafik by seperating him from his family, religion, his sense of honor and duty. Her selfishness turned Rafik, once a loyal husband and father, away from his family. As it is evident from these lines by his first wife:

"I am writing to you because you have not been home in so many months more than eighteen months and your sons and also I miss you." (Mueenuddin, 2008, p.45). Later Saleema confesses to her selfishness in these words: "No, she said, I've done you wrong" (Mueenuddin, 2008, p.45)

Another aspect that the deconstructive analysis of the story brings to light is the subversion of the power dynamics. In his collection of short stories, Daniyal Mueenuddin has reflected upon the Pakistani patriarchal society where all the power resides with men. They are placed at a higher pedestal than women, who are inferior in every respect. Since men hold all the power they are the ones who get to make every decision, whereas women are expected to blindly follow them and do whatever they are asked to do. But in the story these power dynamics have been reversed, where men used to dominate now a woman is shown to have the power and control, thus breaking stereotypical male dominance.

In this story "Saleema", the power resides with the female protagonist Saleema. She is the one who earns and supports her family including her husband and her father, while they waste away doing nothing except drugs. Since she is the sole bread winner of the family she 
holds the authority in her house and treats her husband as she wills. As it is quite evident from these lines:

"Though he knew right away that she slept with Hassan the cook, , in the house where she served as a maid, the first time he opened his mouth she made to slap him and pushed him out of the room." (Mueenuddin, 2008, p.20)

Saleema always has the controlling position. When she had an affair with Hassan, he made dishes that suited her taste. As it has been mentioned: "The entire household, from the sahib on down, had been eating to suit her appetite." (Mueenuddin, 2008, p.21)

Mueenuddin has also unconsiously placed Saleema on a higher position as compared to the other male characters through their description. He has associated all the positive images with Saleema whereas men are described in negative terms. Saleema is described as having an "oval face, taller than broad, with deep set eyes, had a grace contrasting with her bright easy temperament" (Mueenuddin, 2008, p. 20). Whereas her husband is said to have an "emancipating face" and "rotting yellow teeth" (Mueenuddin, 2008, p. 39). While comparing her with Rafik we are told that she is "exactly as tall as him" (Mueenuddin, 2008, p.34) which further establishes her as a force to reckon with and not just a lowly, mute creature.

The above discussion proves that the character of Saleema in this short story is not a weak one who is oppressed and manipulated by the male members of the community. Rather it a character of great strength, one who refuses to give up and makes use of any any resources available in order to survive.

\subsection{CONCLUSION}

It can be concluded that Deconstructive approach aims to bring out the uncounscious of the text. İt rests on the inability of language to convey a single fixed meaning, thus challenging the established notions. This was evident through the application of Derrida's concept of fluidity of meaning and Cuddon's idea of reversal of porality of binary oppositions on Daniyal Mueenuddin's short story "Saleema". The deconstructive analysis of this story revealed that the author has unconsciously given a different dimension to Saleema's character. She is not as vulnerable and subjugated as it appears on the surface level. She continuously defies the limitations imposed on her by the society and ultimately survives by any means possible.

According to the deconstructive reading, the story "Saleema" subverts the power dynamics of the Pakistani society where men are the dominant force and women are the submissive ones. The character of Saleema holds the authority, she has the ultimate control over all the men she has been with, whereas all the men are weak and pathetic. Mueenuddin has also privileged her over men through positive character description.

\section{REFERENCES}

Barthes, R., Miller, R., \& Howard, R. (1975). The pleasure of the text. New York: Hill and 
UNIVERSITY OF CHITRAL JOURNAL OF LINGUISTICS AND LITERATURE

VOL. 1 | ISSUE I | JULY - DEC | 2017

ISSN (E): 2663-1512, ISSN (P): 2617-3611

Wang. Bauman, Z. (1992). Intimations of Postmodernity. New York: Routledge Publishing, pp 150-172.

Beauvoir S.de. (1997). The Second Sex (Vintage Classics ed.). (Parshley HM, Trans.)

Vintage Classics.

Berry, P. (2002). Beginning theory: An introduction to literary and cultural theory.

Manchester: University Press.

Bertens, H. (2003). Literary theory: the basic. London and New York: Routledge; Taylor \& Francis Group

Cixous, Hélène. (2001). "The Laugh of the Medusa." The Norton Anthology of Theory and Criticism. New York: W.W. Norton \& Company.

Cuddon, J. A. (1991). Dictionary of literary terms and literary theory. $3^{\text {rd }}$ Ed. London: The Penguin Publishers.

Culler, J. (2007). On Deconstruction: Theory and Criticism after Structuralism. London: Cornell University Press, $307 \mathrm{pp}$.

Derrida, J. (1976). Of Grammatolgy. Ed. Trans. Gayatri Spivak Chakarvort. Baltimore: John Hopkins University Press. 154; 244

Derrida, J. (1979). "Living on border lines.” Deconstruction and criticism. Ed. Harold Bloom, et al. New York: Seabury Press. 83-84

Edgar, A. \& Sedgwick, P. (2007). Cultural Theory: The Key Concepts. London: Routledge Publishing, pp 447.

Elam, D. (1994). Feminism and deconstruction: Ms. en abyme. London: Routledge.

Hai, Ambreen. (2016). Postcolonial Servitude: Interiority and System in Daniyal Mueenuddin's In Other Rooms, Other Wonders. Baltimore: The John Hopkins University Press.

Haider, F. (1994). The Cow. In Fakhar Zaman \& Ifitkhar Arif (Eds.) Pakistani literature: Special issue women's writings (pp. 127-130). Islamabad: The Pakistan Academy of Letters

Hancock, P and Tyler, M (2001). Work, postmodernism and organization, 1st Edition. London: Sage Publications, p 41

Moi, T. (2001). What is a woman?: And other essays. Oxford: Oxford University Press.

Mueenuddin, Daniyal. (2008). "Saleema". In Other Rooms, Other Wonders (1st ed). London: Bloomsbury.

Munir, Jawairia. (2013). Poststructuralist (Deconstructive) approach to Tariq Rahman "es short story "Bingo". Retrieved from https://www.scribd.com/

Said, Mushba. (2016). Manto \& Mueenudin: A Brief Analysis of Who is The Authentic Voice of the Subaltern. Retrieved from https://www.academia.edu/

Showalter, E. (1999). A literature of their own: British women novelists from Brontë Lessing. Princeton, N.J: Princeton University Press. 
UNIVERSITY OF CHITRAL JOURNAL OF LINGUISTICS AND LITERATURE

VOL. 1 | ISSUE I | JULY - DEC | 2017

Tyson, L. (2006). Critical theory today: A user-friendly guide (2nd ed.). New York: Routledge. Vincent, L. B. (1983). "Extension of subversion." In deconstructive criticism: An advance introduction. New York: Columbia University Press.

\begin{tabular}{|l|l|}
\hline CC 2017 by the author. Licensee University of Chitral, Journal of Linguistics \& \\
Literature, Pakistan. This article is an open access article distributed under the \\
terms and conditions of the Creative Commons Attribution (CC BY) \\
(http://creativecommons.org/licenses/by/4.0/).
\end{tabular}

